Отримано: 18 травня 2018 р.

Прорецензовано: 26 травня 2018 р.

Прийнято до друку: 30 травня 2018 р.

e-mail: dklimenko70@gmail.com

DOI: $10.25264 / 2311-5149-2018-9(37)-125-130$

Клименко Д. Б. Механізм державного регулювання проблемних кредитіві. Наукові записки Начіонального університету "Острозька академія». Серія «Економіка»: науковий журнал. Острог : Вид-во НаУОА, червень 2018. № 9(37). С. 125-130.

Клименко Дмитро Борисович,

кандидат економічних наук, дочент, кафедра банківської справи та фінансового моніторингу,

Університет державної фіскальної служби Украӥни

\title{
МЕХАНІЗМ ДЕРЖАВНОГО РЕГУЛЮВАННЯ ПРОБЛЕМНИХ КРЕДИТІВ
}

У статті подано характеристику кредитного портфеля банківської системи України на сучасному етапі розвитку. Проаналізовано склад кредитного портфелю з визначенням частки проблемних кредитів. Розглянуто необхідність комплексного впровадження механізму в роботі з проблемними кредитами. Надано оиінку дій банку в роботі з проблемними кредитами. Проаналізовано нормативно-законодавчі акти, дії яких спрямовані на роботу кредиторів i боржників щодо обслуговування заборгованості. Акиентовано увагу на важливості і необхідності безпосередньої участі держави у зменшенні частки непрацюючих кредитів для подальшого розвитку кредитного ринку в країні.

Ключові слова: капітал банку, кредитний портфель, кредитор, проблемні кредити, реструктуризація, банкрутство.

\section{Клименко Дмитий Борисович,}

кандидат экономических наук, доцент, кафедра банковского дела и финансового мониторинга,

Университет государственной фискальної служббы Украины

\section{МЕХАНИЗМ ГОСУДАРСТВЕННОГО УПРАВЛЕНИЯ ПРОБЛЕМНЫМИ КРЕДИТАМИ}

В статье дана характеристика проблем кредитного портфеля современной банковской системы Украины. Приведен анализ состава кредитного портфеля, определена доля проблемных кредитов. Рассматривается необходимость комплексного внедрения механизма работы с проблемными кредитами. Дана оценка работы банков по работе с проблемными кредитами. Приведен анализ нормативной и законодательной базы, направленной на совместную работу кредитора и должника по обслуживанию задолженности. Акцентировано внимание на важности и необходимости участия государства в решении проблем неработающих кредитов, что влияет на дальнейшее развитие кредитного рынка в стране.

Ключевые слова: кредитный портфель, неработающие кредиты, проблемная задолженность, капитал банка, реструктуризачия, банкротство, кредитор.

\author{
Dmitry Klymenko, \\ Ph. D. in Economics, Associate Professor, Department of Banking and Financial Monitoring, \\ University of the State Tax Service of Ukraine
}

\section{MECHANISM OF PROBLEM LOANS REGULATION BY STATE}

The article describes the characteristics of Ukraine's banking system loan portfolio at its present stage of development. The loan portfolio composition with the definition of the problem loans share is analyzed. The necessity of implementing complex mechanism of the work with problem loans is considered. An assessment of the bank's activities with problem loans is given. The normative and legislative acts, aimed at the work of creditors and debtors on debt servicing, are analyzed. The importance and necessity of state's direct participation in reducing the share of non-working loans for further development of the credit market in the country was highlighted.

Key words: loan portfolio, inactive loans, problem debt, bank capital, restructuring, bankruptcy, creditor.

Постановка проблеми. Економіка країни зазнає вагомих втрат унаслідок перманентних економічних і політичних криз. Результатом цих криз є обмеження і значне зменшення обсягів кредитування реального сектору економіки банками. Наразі відчувається найбільше падіння банківського кредитування на фоні якості кредитних портфелів. Значна частка проблемної заборгованості у структурі кредитних портфелів банків призводить до негативного фінансового результату та привертає увагу рівень капіталізації банків. Обсяги проблемних кредитів не тільки спонукають проблеми ліквідності та фінансові проблеми банку, а й позначаються на довірі суспільства до банків. Тому в банківській діяльності актуальною є проблема оцінки проблемних кредитів і розробка негайних заходів із боку держави щодо виправлення вкрай незадовільного стану роботи із проблемною заборгованістю. 
Крім того, кардинально зменшити кількість проблемних кредитів - одне із стратегічних завдань держави до 2022 року.

Аналіз останніх досліджень і публікацій. Традиційно, що кредитна діяльність банків завжди перебуває в центрі уваги науковців і під щільним наглядом регулятора. Водночас аналіз роботи з проблемними кредитами знаходиться у центрі уваги.

Питанням дослідження проблемних кредитів, аналізу їх стану та методи роботи з ними завжди цікавили як зарубіжних, так і вітчизняних учених і практиків. Вагомий внесок у вивчення питань проблемної заборгованості й ефективності управління токсичними кредитами зробили В. Д. Базилевич, І. В. Сало, О. Д. Вовчак, І. О. Барановський, Л. О. Примостка, Дж. Бессис, П. Роуз.

Здебільшого роботи зорієнтовані на дослідженні концентрації кредитних портфелів окремих банків і побудові моделей роботи з проблемними кредитами безпосередньо банками, а питання концентрацій банківської системи України та винесення питання на державний рівень залишаються відкритими для дослідження.

Метою дослідження є виявлення практичних заходів щодо впровадження державної політики, спрямованої на розширення механізмів роботи з проблемними кредитами й оцінці перспектив їх використання.

Виклад основного матеріалу. Однією з головних причин кризи на банківському ринку України стала значна кількість неповернених позичальниками кредитів банкам. У 2017 році Україна встановила сумнівний світовий рекорд за обсягом проблемних кредитів. Вони у вітчизняній банківській системі складають понад 50\%, у державних банках взагалі сягають $75 \%$.

За визначенням НБУ недіючі кредити (nonperforming loans (NPL)) - це сумнівні та безнадійні до повернення кредити. За рекомендаціями МВФ, недіючими вважають усі кредити, прострочка із виплатіияких перевищила 90 або більше днів. У вітчизняній практиці до недіючих кредитів відносять сумнівні та безнадійні кредити. Поряд із недіючими кредитами виділяють також поняття «проблемні кредити». До складу проблемних включають прострочені та сумнівні. Фактично до проблемних кредитів відносять усю суму прострочених платежів за кредитом [3].

До кризи 2008 року банки досить активно кредитували населення і бізнес як у національній, так і в іноземній валютах. Це призвело до великої кількості неплатежів по кредитах у зв’язку з девальвацією гривні і падінням економіки.

Слід зазначити, що у 2010-2013 роках банкам вдалося частково стабілізувати ситуацію, але у зв'язку 3 черговою кризою 2014 року, внаслідок якої національна валюта девальвувала, а також у зв'язку з початком бойових дій на Сході України, частка проблемної заборгованості значно зросла.

За даними НБУ, в Криму та зоні бойових дій Донецької і Луганської областей (АТО) банки втратили кредитів на близько 80 мільярдів гривень. До того ж, деякі боржники просто не повертають банкам гроші.

Однак першопричинами, на нашу думку, є внутрішні чинники виникнення проблемної заборгованості, пов'язані з діяльністю самого банку, а саме: неповна або недостовірна інформація про позичальника; недостатньо продумана і розроблена кредитна політика банку; неякісна оцінка кредитоспроможності позичальника; недостатній рівень контролю за позичальником після видачі кредиту; великий сегмент пов'язаних кредитів, які видавалися завідомо без мети їх повернення.

За даними Фонду гарантування вкладів, більша частка проблемних боргів неплатоспроможних банків припадає на 600 бізнес-груп, які разом винні їм майже 180 мільярдів гривень, і не обслуговують кредити.

3 урахуванням того, що нині весь кредитний портфель банківської системи складає близько 1 трильйона гривень, боржники не обслуговують позики на 568,8 мільярда гривень (рис. 1).

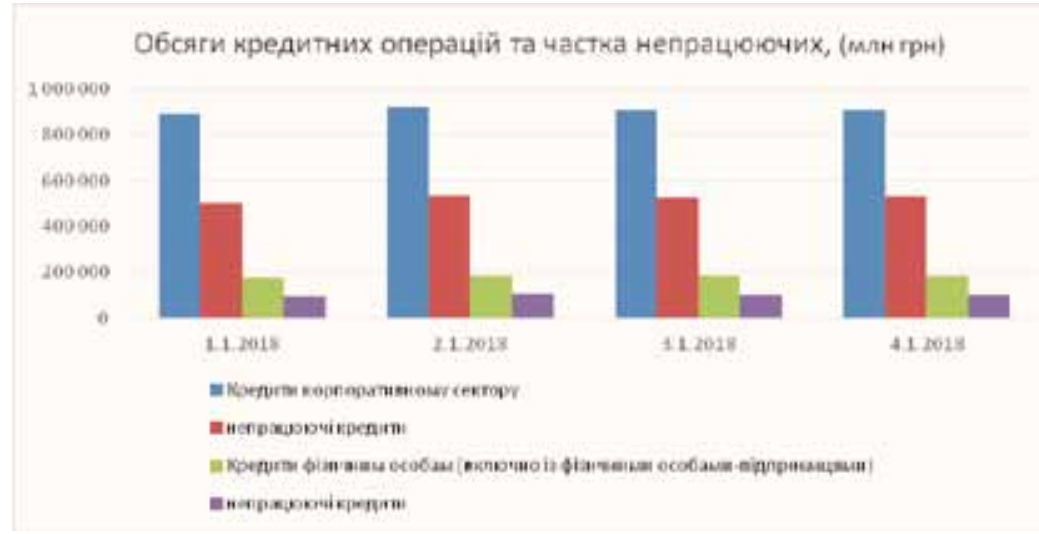

Рис. 1. Обсяги кредитних операцій i частка NPL у банківській системі України (складено автором на основі статистичних даних НБУ (показники банківської системи) [6]) 
Частка непрацюючих кредитів в обсязі активних операцій у банківській системі залишається дуже великою і коливається в межах від $22 \%$ до $82 \%$ (рис. 2).

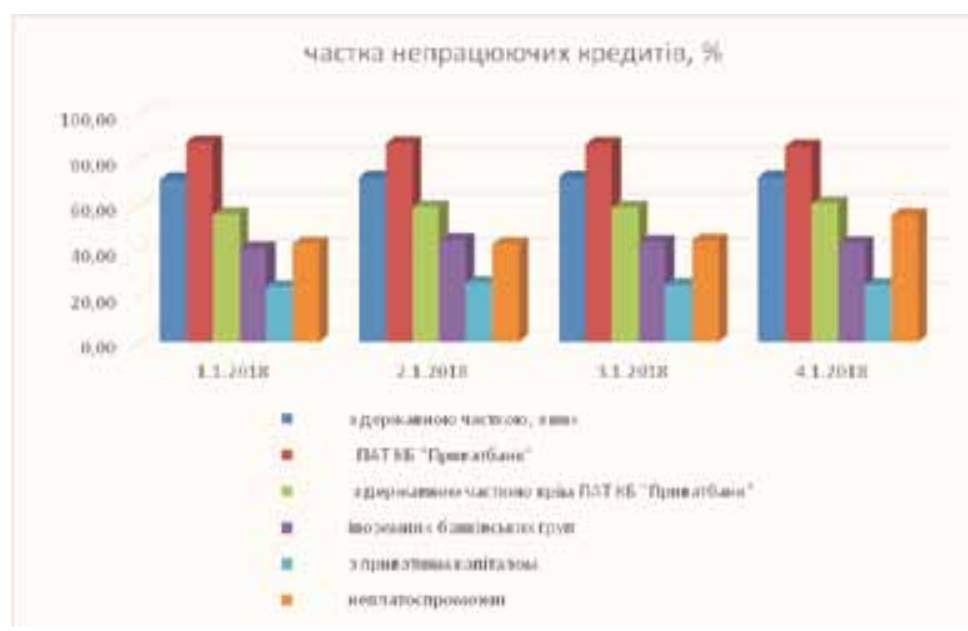

Рис. 2. Частка непрацюючих кредитів в обсязі активних операцій загалом у банківській системі України за період 01.01.2018 p. - 01.04.2018 p. (складено автором на основі статистичних даних НБУ (показники банківської системи) [6])

Такий стан результатів кредитування не може лишати осторонь державу, вимагає чітких і зрозумілих дій для вирішення цієї проблеми, адже фінансові установи не можуть вести повноцінної діяльності не позбувшись баласту проблемних кредитів (нормативи НБУ зобов'язують банки формувати резерви на всю суму заборгованості).

Наразі можна зазначити певні дії регулятора спрямовані на подолання такого стану речей. Так, наприкінці 2017 року НБУ відстрочив на два роки термін збільшення статутного капіталу банків до 300 млн грн - далась взнаки тенденція щодо стабілізації фінансової системи України. Тепер мінімальний розмір регулятивного капіталу банку, який отримав банківську ліцензію до 11 липня 2014 року, має становити 300 млн грн із 11 липня 2020 року, 400 млн грн - ще через два роки, а 500 млн грн - із 11 липня 2024 року.

Зазначимо, що до жовтня 2017 року навіть половина українських банків не мали статутного капіталу у 300 і більше млн грн. У меморандумах з Україною МВФ рекомендував вирішувати питання недостатності капіталу банків завдяки вливанню грошових коштів або виводженню банків із ринку, якщо їхній капітал не збільшиться. Але власники і топ-менеджмент недокапіталізованих банків дотримувались іншої думки, що, по-перше, не всім фінансовим установам через специфіку їхньої роботи на ринку така докапіталізація потрібна, а по-друге, не всі їі можуть здійснити фізично. На цьому фоні кількість проблемних кредитів продовжує зростати. Регулятор змінив терміни збільшення статутного капіталу не тільки через стабілізацію банківської системи, а й більшою мірою через неготовність банків збільшувати свій капітал, та й, можливо, відсутність такої реальної необхідності. До того ж, схоже, регулятор розвів проблеми капіталу і проблемних заборгованостей. Якщо дедлайн збільшення статутного капіталу перенесено, то друга проблема вимагає термінового вирішення, щоб зменшити потреби в капіталі. Процес оптимізації розпочався з переоцінки активів у банківській системі. Виявилося, що вартість активів не завжди $є$ ринковою і порушені процесуальні питання до деяких банкірів з усіма юридичними наслідками.

Аналіз наявного процесу роботи банків із проблемними кредитами сьогодні дає змогу зробити ряд зауважень.

По-перше, це забюрократизований процес для будь-якого банку. Вирішенням поставленого завдання займаються різні підрозділи: софт-колекшен - виокремлений відділ по роботі з проблемними кредитами, юридичний підрозділ веде судові процедури, а виконання судових рішень інший підрозділ. Наскільки ефективний такий розподіл можна побачити по зростаючій динаміці портфеля проблемної заборгованості. Таким чином, процес ускладнюється через неповороткість банківської структури, встановлені внутрішні бюрократичні процедури і перепони тоді, коли прийняття рішень і їх виконання спрямовані на роботу з боржниками вимагає швидкої реакції.

Друге зауваження стосується оформлення і переоформлення застав за позикою у разі продажу портфелю проблемних кредитів. Якщо портфель реалізується з дисконтом то гостро постає питання оподаткування.

По-третє, терміни оформлення продажу портфеля проблемних кредитів можуть тривати достатньо, щоб пропустити терміни позовної давності і це зводить нанівець зусилля стягнення заборгованості в перспективі. 
Четверте зауваження стосується адвокадської монополії, яка звужує можливості банків самостійно займатися стягненням заборгованості в судовому порядку, оскільки вести справи в судах можуть тільки адвокати. У штаті більшості банків не передбачаються адвокатські одиниці. На перехідний період 2018 року передбачено що справи можуть вести юристи без адвокатського свідоцтва, але в найближчій перспективі це питання не вирішено.

Поки банки налагоджують індивідуальну роботу зі своїми портфелями проблемних кредитів, звернемо увагу на ті кроки і заходи, які має намір запровадити та вже здійснює держава для вирішення питання проблемної заборгованості.

Так, із метою створення дієвого механізму добровільної фінансової реструктуризації боргів підприємств України та їх досудової санації Верховною Радою України у 2016 році було прийнято Закон «Про фінансову реструктуризацію». Відразу зазначимо, що цей закон не є механізмом ухилення від сплати по кредитах. Документ дозволяє запровадити банкам та іншим кредиторам механізм реструктуризації та обслуговування боргу. На нашу думку, Закон слід розглядати як додатковий юридичний механізм проведення фінансової реструктуризації кредитів, що дасть змогу підвищити класність кредитів у розумінні НБУ та, як наслідок, розформування резервів.

До того ж, закон підготовлений із метою відновлення банківського кредитування й економічної активності боржників.

Такий документ - не екслюзивний національний винахід, подібні закони були прийняті у країнах, що постраждали від Азійської фінансової кризи кінця 90-х (Малайзії, Південній Кореї, Таїланді), у Туреччині (після фінансової кризи в цій країні 2001-2003 pp), у Хорватії, Чорногорії, Сербії. Прийняття законів значно сприяли вирішенню питання, пов'язаного з непрацюючими кредитами та відновленням банківського і корпоративного секторів у цих країнах.

Ощадбанк став першим із найбільших банків і першим державним банком, який скористався положеннями нового Закону України «Про фінансову реструктуризацію», використавши власний набір інструментів реструктуризації грошових зобов'язання та пільг, передбачених законом.

Процедуру реструктуризації було запущено 15 червня 2017 року, одночасно було запроваджено мораторій на задоволення вимог кредиторів. Із завершенням реструктуризації компанії VIDI Group спромоглися вийти зі стану дефолту та в повному обсязі поновлюють виконання взятих на себе зобов'язань перед кредитором.

На жаль, таких прикладів небагато. До того ж, слід зауважити на тимчасовість такого механізму (Закон набрав чинності 19 жовтня 2016 року терміном на 3 роки). Тимчасовий характер закону розрахований на вирішення специфічних наявних посткризових обставин у країні. Крім того, тимчасовість має заохочувати сторони до його застосування протягом терміну дії, інакше вони не отримають переваг. Якщо закон буде діяти на постійній основі, у сторін не буде жодних стимулів його застосовувати і цілі прискореного відновлення економіки не будуть досягнуті.

Отже, Закон України «Про фінансову реструктуризацію» покликаний врегулювати заборгованість без звернення до суду, з використанням дієвих механізмів здійснення ефективної фінансової реструктуризації за допомогою нових незалежних органів: Спостережної ради, Секретаріату й Арбітражного комітету (з обов'язковим отриманням моніторингового звіту незалежного експерта фінансово-господарської діяльності боржника, який містить висновок про перспективність такої діяльності).

Наступним важливим кроком, як зазначає банківська спільнота, буде ухвалений Верховною Радою в першому читанні законопроект №8060 щодо Кодексу України з процедур банкрутства. На жаль, більшість сучасних банкрутств використовуються боржниками переважно для ухиляння від виконання своїх грошових зобов'язань, що зводить нанівець усю роботу банку з проблемною заборгованістю та породжує правову безвихідь.

Нововведення щодо корпоративного банкрутства передбачають:

- створення ефективних механізмів позасудового врегулювання;

- підвищення рівня захищеності прав усіх кредиторів (передача ключових повноважень від комітету кредиторів зборам кредиторів;

• скорочення термінів розгляду справ, зокрема, за рахунок зменшення кількості оскаржень;

- забезпечення реалізації всього майна боржника виключно на електронному аукціоні за найвищою ціною.

Щодо фізичних осіб, то пропонується встановити мінімальні бар'єри для участі громадян у простій і зрозумілій процедурі відновлення їх платоспроможності, а також передбачити участь у процедурі арбітражного керуючого, який допоможе громадянинові оцінити його фінансові проблеми.

Сподіваємося, що прийняття кодексу запустить швидкий та ефективний інструмент повернення активів.

Отже, як бачимо, оптимізація правового поля покликана захистити права кредиторів і створює сприятливі умови для реструктуризації боргів. Але, на нашу думку, необхідно окреслити ще декілька важ- 
ливих питань, як то - вирішення податкових проблем у роботі з проблемними активами та створити компанію з управління заборгованістю.

Наразі обговорюються і заслуговують уваги ще ряд різних ініціатив із боку регулятора і держави - це і створення спеціалізованої компанії з управління активами, яка займалася б проблемними активами всієї банківської системи, і злиття в один банк усіх проблемних кредитів держбанків, і передача проблемних кредитів до Фонду гарантування вкладів фізичних осіб для їх подальшої реалізації через Prozzoro.

Доречно згадати, що держава вже має досвід роботи $з$ проблемними активами банків, але він - негативний. Подібну функцію мав виконувати націоналізований у 2009 році «Родовід Банк». Уряд капіталізував його на 2,35 млрд грн. Але це йому не допомогло - «Родовід Банк» не лише не зміг узяти в роботу проблемні активи інших банків, а й не спромігся розібратися з власними. Національний банк підрахував, що 92\% усіх його кредитів були проблемними і він потребував додаткової державної підтримки. Державі не вдалося отримати доходи від роботи цього банку. Як потім повідомив Національний банк - протягом діяльності «Родовід Банку», як санаційного, його доходи покривали лише витрати, держава не мала жодних доходів від його діяльності. Зрештою наприкінці 2016 року «Родовід Банк» було визнано неплатоспроможним.

Водночас самі банкіри вважають, що лише роботи такої структури буде недостатньо для вирішення питань із проблемною заборгованістю у їх кредитних портфелях. Більш корисним для банків у частині очищення балансу було б надання податкових преференцій при списанні проблемної заборгованості, а також звільнення фізичних осіб від податку на прибуток у разі списання частини заборгованості.

Беручи до уваги негативний досвід роботи санаційного банку, НБУ пропонує створити компанію 3 управління заборгованістю. Регулятор має надію, що правове забезпечення такої структури сприятиме не просто розв’язанню проблем токсичних кредитів і приходу приватного капіталу на ринок проблемних кредитів, а й допоможе відновленню кредитування.

На останок, відзначимо, що, починаючи з 2017 року, фінансовий ринок України визначається певною стабілізацією ситуації, а банківські установи характеризуються достатньою ліквідністю і наявністю ресурсів. Це значить, що під час вирішення низки проблем, яка містить і NPL, в Україні очікується зростання обсягу нових кредитів. Перший крок було вже зроблено - у 2017 році банки зробили ставку на масовий продаж споживчих кредитів і не помилилися. За даними НБУ, відсоток проблемної заборгованості за такими кредитами найнижчий, і за рік частка проблемних кредитів навіть зменшилася на 5,06 п.п. (3 $27,2 \%$ до 22,14\%). Але цей сегмент у перспективі двох років стає ризиковим. По-перше, збільшиться вартість кредитів для населення. За останні кілька місяців НБУ з метою стримати зростання цін підвищив облікову ставку з 13,5\% до 17\%. Саме тому міжбанківські позики стали дорожчими - а це значить, що приблизно на 70\% від зростання облікової ставки можуть подорожчати і кредити в приватних банках. Наприклад, із жовтня 20017 року по березень 2018 року облікову ставка підвищилася на 3,5 відсоткових пунктів - за цей же час ставки по кредитах для юридичних осіб зросли на 2 відсоткові пунти, а для фізичних осіб на 3 відсоткові пункти. Водночас як це корелюється із стратегією розвитку банківського сектора, де йдеться про зниження до 2022 року банківської ставки на 22 процентних пунти, лишається відкритим питанням. По-друге, збільшився сегмент інших гравців на ринку споживчого кредитування. Фінансові аналітики стверджують, що банки вже відчувають конкуренцію на ринку короткострокових позик з боку дрібних фінансових установ на кшталт ломбардів і кредитних спілок. Наприклад, за останній квартал 2017 року банки видали споживчих кредитів на 7,4 млрд грн, а ломбарди - на 3,9 млрд грн. Третій фактор - збільшиться ймовірність неповернення кредитів, виданих у 2016 році, що пов'язано із зростанням курсу долара й інфляцією. Що ж, проблемних кредитів знову стане більше, з якими мають упоратись компанії з управління заборгованістю, які будуть запропоновані державою.

Висновки. Отже, у результаті дослідження можна зробити висновок, що баланси банків нині перевантажені проблемними боргами. Значна кількість проблемної заборгованості в кредитних портфелях банків протягом тривалого часу вказує на те, що банки самотужки таку проблему вирішити не в змозі. Крім того, такий стан речей свідчить, що банки практично не захищені перед недобросовісними клієнтами. Дослідження свідчить про необхідність поєднання зусиль банків із державним прагненням вирішення питання проблемних кредитів, шляхом створення дієвого механізму державного регулювання їх.

Завдяки гармонізації фінансового законодавства з нормами цивільного права України, та врахування світового досвіду буде можливим оперативно й ефективно працювати на повернення проблемних боргів.

Закон України «Про фінансову реструктуризацію», безперечно дієвий та ефективний механізм компромісу банка та позичальника спрямований на врегулювання проблемної заборгованості і поліпшення якості кредитного портфелю.

На переконання правників, для захисту прав кредиторів необхідно встановити договірний механізм врегулювання і валютних кредитів фізичних осіб, і ввести інститут приватного виконання рішень. Уважаємо, що найближчим часом буде скасовано мораторій на стягнення іпотечного майна і скоротяться процедури відчуження об’єктів застави. На порядку денному також удосконалення процедури продажу

Наукові записки Національного університету «Острозька академія», серія «Економіка», № 9(37), червень, 2018 р. 
арештованого майна. Позитивним моментом, на нашу думку, буде і звільнення боржників від сплати податку на прибуток, нарахований у разі прощення боргу.

Крім того, потребує розвитку сам ринок продажу проблемних кредитів. Чіткі правила для торгівлі проблемними кредитами сприяли б залученню інвестицій від міжнародних професійних учасників вторинного ринку кредитів.

\section{Література:}

1. Закон України «Про фінансову реструктуризацію». URL: http//zakon2.rada.gov.ua/laws/show/1414-19 (дата звернення: 18. 05.2018).

2. Звіт про фінансову стабільність. URL: https://bank.gov.ua/doccatalog/document?id=60764561 (дата звернення: 18. 05.2018).

3. Інтернет-представництво НБУ. URL: https://bank.gov.ua/control/uk/publish/article?art_id=123459 (дата звернення: 18. 05.2018).

4. Морсманол Э. М. управление кредитным портфелем / Э.М. Морсманол ; пер. с англ. - М. : Альпина бизнес букс, 2004. -208 с.

5. Примостка Л. О. Фінансовий менеджмент у банку: підручник. - 2-ге вид., доп. і перероб. / Л. О. Примостка. - К.: КНЕУ, 2004. - 468 с.

6. Показники банківської системи. URL: https://bank.gov.ua/control/uk/publish/article?art_id=34661442\&cat_ id $=34798593$ (дата звернення: 18. 05.2018).

7. Проект Кодексу України 3 процедур банкрутства. URL: http://w1.c1.rada.gov.ua/pls/zweb2/ webproc4_1?pf3511=63518 (дата звернення: 18. 05.2018).

8. Про затвердження Положення про визначення банками України розміру кредитного ризику за активними банківськими операціями. URL: http://zakon0.rada.gov.ua/laws/show/v0351500-16/page (дата звернення: 18. 05.2018). 